\title{
Labyrinthe
}

2| 1999

Numéro 2

\section{L'écriture de la mort des personnages dans À la recherche du temps perdu}

\section{Stéphane Girardon}

\section{(2) OpenEdition \\ 12 Journals}

\section{Electronic version}

URL: http://journals.openedition.org/labyrinthe/372

DOI: $10.4000 /$ labyrinthe. 372

ISSN: 1950-6031

\section{Publisher}

Hermann

\section{Printed version}

Date of publication: 15 January 1999

Number of pages: 116-118

\section{Electronic reference}

Stéphane Girardon, "L'écriture de la mort des personnages dans À la recherche du temps perdu », Labyrinthe [Online], 2 I 1999, Online since 04 March 2005, connection on 06 May 2019. URL : http:// journals.openedition.org/labyrinthe/372 ; DOI : 10.4000/labyrinthe.372

This text was automatically generated on 6 May 2019.

Propriété intellectuelle 
L'écriture de la mort des personnages dans À la recherche du temps perdu

Stéphane Girardon 